\title{
ЕКОНОМІЧНА БЕЗПЕКА ТА ТРАНСПАРЕНТНІСТЬ ПІДПРИЄМСТВ В УМОВАХ ЦИФРОВІЗАЦІї
}

У статті здійснено дослідження сутності економічної безпеки в умовах цифровізації. Визначено особливості забезпечення економічної безпеки, в тому числі з урахуванням транспарентності підприємств у сучасних умовах розвитку цифрових технологій. Систематизовано цифрові загрози економічній безпеці та визначено базові з них для підприємницького сектору. Сформовано таксономію транспарентності підприємств та концепт діяльності підприємств, що враховує межі транспарентності, які б нейтралізували загрози їх економічній безпеці. За результатами аналізу індексу прозорості підприємств надано рекомендації 3 підвищення рівня транспарентності вітчизняних підприємств на засадах цифровізації та 3 урахуванням загроз економічній безпеці.

Ключові слова: економічна безпека; цифровізація; загрози; підприємство; транспарентність.

Вступ. На сьогодні економічна безпека $€$ найважливішою умовою стабільності та досягнення ефективних результатів діяльності окремих підприємств, держави та суспільства в цілому. Пріоритетним завданням забезпечення економічної безпеки, особливо помітним в мінливих умовах сучасного глобального світу, $\epsilon$ передбачення викликів і загроз, до реалізації яких необхідно готуватися вже сьогодні. Одним з важливих глобальних викликів сьогодення є загальна цифровізація. Адже швидкий розвиток даної сфери $є$ джерелом раніше невідомих ризиків та загроз, що, відповідно, вимагає вироблення нових принципів та заходів їх мінімізації та ліквідації.

До того ж в умовах цифровізації зростає необхідність забезпечення транспарентності підприємств. Адже відкритість інформації щодо організації бізнесу, впровадження інновацій та корпоративної соціальної відповідальності $є$ критерієм якості управління діяльністю підприємств, що визначає їх інвестиційну 
привабливість та зростання ринкової вартості.

Саме тому проблеми забезпечення економічної безпеки у взаємозв'язку з принципами транспарентності в умовах розвитку глобальної мережі економічних та соціальних процесів набувають все більшої актуальності. При цьому транспарентність підприємств повинна мати межу, яка б дозволила нейтралізувати загрози економічній безпеці, та сприяла б укріпленню їх конкурентних позицій на ринку.

Аналіз останніх досліджень i публікацій. Проблемам забезпечення економічної безпеки в умовах цифровізації на рівні підприємства присвячено достатня кількість наукових праць як вітчизняних, так і закордонних вчених: J.Scott, I. Демченко, Т.Кривцова, А. Кубайченко, Ю. Лядова, В.Нехая, Є.Попова, К. Семячкова, Г. Соломіна, О. Сталінської, С. Фролова, О. Яцюк та ін. Концепцію транспарентності також досліджує досить широке коло науковців, серед яких A. Boone, P. Martíšková, J. White, І. Білоцька, В. Козуб, Н. Краснокутська, О. Круглова, О. Сироватський, В. Халіна, Р. Хубієв та ін.

Проте, на сьогодні питання взаємозв'язку та взаємозалежності таких понять як економічна безпека та транспарентність в нових умовах цифрової економіки $€$ недостатньо дослідженим. Зокрема, проблема забезпечення економічної безпеки 3 урахуванням концепції транспарентної діяльності підприємства в умовах цифровізації потребує активних досліджень. Адже виклики цифрової економіки формують нові специфічні загрози та ризики як для окремого підприємства, так і для держави в цілому.

Постановка завдання. Метою статті $€$ систематизація загроз забезпечення економічної безпеки підприємств в умовах розвитку глобальної цифровізації, а також визначення місця та ролі транспарентності у даному процесі.

Для досягнення мети необхідно розкрити сутність та особливості забезпечення економічної безпеки підприємств, в тому числі 3 урахуванням їх транспарентної діяльності в умовах цифровізації, сформувати концепт діяльності підприємств 3 урахуванням меж транспарентності, які б нейтралізували загрози їх економічній безпеці.

Виклад основного матеріалу. Термін «економічної безпеки» в Україні було введено в науковий обіг на початку 90-х років, що обумовлено процесами здобуття незалежності країни, необхідністю виходу із системної кризи та досягнення національних, зокрема економічних інтересів. Однак, дана категорія не втрачає наукового 
інтересу у сучасних наукових дослідженнях та практиках. Звісно, це пояснюється тим, що суспільство перейшло до наступного етапу свого розвитку - фази ризику. Це вимагає розробки заходів щодо підвищення рівня захисту від факторів ризику.

Також, варто відмітити, що на сьогодні, економічна безпека відіграє надзвичайно важливу роль як для окремого підприємства, так і для суспільства в цілому. Адже ця категорія лежить у площині взаємозв'язку мікро- та макрорівнів. У наукових працях показано, що економічна безпека окремої держави забезпечується стабільним розвитком підприємницького сектору [1], тобто економічна безпека суспільства пов'язана з умовами ведення бізнесу [2]. Також економічна безпека суспільства забезпечується громадським фінансовим контролем [3] і розмірами впливу тіньової економіки [4]. У свою чергу, інституційна інфраструктура суспільства у взаємозв'язку 3 принципами транспарентності обумовлює економічне зростання і зниження господарських загроз.

Широкомасштабні зміни на основі впровадження цифрових технологій, значно розширюють масштаби проблеми забезпечення економічної безпеки. Ефективне управління ризиками в умовах розвитку цифрового простору має велике значення для реалізації економічних питань і соціальних переваг цифрової економіки. Формування надійності в нових умовах взаємодії, основою яких $€$ цифрові технології $\epsilon$ важливою умовою соціально-економічної необхідності розвитку сучасних підприємств.

Базовим підходом до визначення сутнісної характеристики «економічної безпеки» $\epsilon$ системний. Згідно даного підходу, економічна безпека підприємства забезпечується обмеженою кількістю взаємозалежних елементів: інтелектуальна, інформаційна, технологічна, маркетингова, правова, екологічна, інноваційна та фінансова [5, С. 81].

В останні роки підприємницький сектор підпорядковуються прогресивним тенденціям у цифровому середовищі, що з економічної точки зору матимуть вплив на кожну зі складових економічної безпеки. Так, з однієї сторони, цифровізація $є$ чинником позитивних змін на репутацію організацій, їх фінансову складову, підвищення рівня конкурентоспроможності й інноваційності бізнесу, а відповідно посилення позиції на ринку. Однак, з іншої сторони, загрози цифрового сектору можуть порушити доступність, цілісність або конфіденційність інформаційних систем, на яких базується економічна діяльність [6].

Отже, з розвитком цифрових технологій виникають нові загрози для підприємницького сектору [7, С. 84]. Таким чином, формується 
складна ситуація, за результатами якої цифрові технології можна розглядати, з одного боку, як чинник розвитку та засіб захисту, а $з$ іншого як джерело загроз.

Слід зазначити, що загрози інформаційної безпеки зародились одночасно з появою інформаційного простору. Спочатку це проявлялось у вигляді крадіжок даних з комп'ютера, нелегального використання цифрової інформації. Згодом дрібні крадіжки перетворились в засоби розповсюдження по мережі неправдивої інформації, вірусів. На сьогодні цифрові загрози відносяться майже до всіх системних складових економічної безпеки.

Таким чином, аналіз літератури дозволяє згрупувати цифрові загрози економічній безпеці у п'ять базових блоків:

1. Системні - загрози, що стосуються економіки або їі значних частин (залежність від цифрових технологій інших держав, відсутність власної елементної бази, проблема «цифрової нерівності»).

2. Структурні - наслідок широкомасштабного впровадження цифрових технологій (наприклад, суттєві зміни на ринку праці і зростання безробіття).

3. Галузеві - відсутність цифрових рішень для окремих галузей (наприклад, відсутність власної платіжної системи).

4. Підприємницькі - формуються у підприємницькому секторі 3 зовнішніх та внутрішніх джерел (наприклад, крадіжки, кібератаки).

5. Особистісні - формуються на рівні окремих громадян (крадіжка, маніпулювання особистими даними).

Розглянемо більш детальніше загрози для окремого підприємства. Відзначимо, що на рівні окремого підприємства загрози можна класифікувати на зовнішні та внутрішні (таблиця).

За результатами дослідження, яке провели фахівці компанії PricewaterhouseCoopers Україна [8], у 2020 році 51\% українських підприємств постраждав від випадків економічних злочинів та шахрайства, порівняно 3 48\% у 2018 році. Найбільш поширеними видами економічних злочинів та шахрайства $є$ : незаконне привласнення майна (47\%), шахрайство з боку клієнтів (31\%), шахрайство у закупівлях (31\%) та кіберзлочини (31\%). Цифрові загрози несуть в собі й інші негативні наслідки для вітчизняних підприємств: заплямування репутації (бренду), погіршення відносини з бізнес-партнерами. 
Загрози економічній безпеці підприємства в умовах цифровізації Вид загроз

Характеристика

$\begin{array}{ll}\text { Зовнішні } & \text { - шахрайство з боку клієнтів; } \\ & \text { - копіювання цінних файлів, пошкодження носіїв з } \\ & \text { інформацією; } \\ & \text { - донесення даних до компаній-конкурентів; } \\ & \text { - викрадення інформації за допомогою інсайдерів; } \\ & \text { - переманювання працівників на інше підприємство; } \\ & \text { - промислове шпигунство, хакерські атаки; } \\ & \text { - недостатня забезпеченість цифровими технологіями, } \\ & \text { компетентними кадрами. } \\ \text { Внутрішні } & \text { - крадіжка корпоративних даних; } \\ & \text { - зараження інформації вірусами або псування документів } \\ & \text { безпосередньо персоналом фірми. }\end{array}$

Як стверджує В. Нехай, негативними наслідками від цифрових загроз для діяльності підприємства можуть стати зниження вартості капіталу підприємства, малий потік інвестицій, втрата вигідних контрактів, зниження цін або обсягів реалізації, негативний вплив на авторитет та ділову репутацію фірми, проблеми в постачанні та придбанні устаткування, банкрутство тощо [9, С. 138].

В умовах цифровізації новим викликом для підприємств $\epsilon$ забезпечення транспарентності, що поєднує принципи прозорості та відкритості їх діяльності. Адже відкритість інформації щодо організації бізнесу, впровадження інновацій та соціальної діяльності $\epsilon$ критерієм культури корпоративного управління підприємством, що при належному забезпеченні створює передумови для зміцнення його конкурентних позицій на ринку, а також визначає інвестиційну привабливість та зростання ринкової вартості підприємства.

Поняття транспарентності поєднує низку якісних характеристик бізнесу та інформації, яку підприємство надає стейкхолдерам: це достовірність, зрозумілість, змістовність, доречність. Більшість вітчизняних науковців [10-11; 14] значення поняття транспарентності пов'язують 3 доступом до інформації щодо соціальних, економічних, політичних, екологічних та інших процесів. Окрім того, зарубіжними науковцями транспарентність розглядається як соціальне явище, як стан інформованості (наявність повних, достатніх та достовірних знань) про ту чи іншу діяльність (ії об'єкти чи результати), яке давало б змогу будь-якому зацікавленому суб'єкту мати повне уявлення про неї [13]. Тобто транспарентність підприємства полягає у інформаційній прозорості (від лат. trans - прозорий, наскрізь; pareo - бути очевидним) або гласності, публічності середовища та інформації, яку підприємство 
надає стейкхолдерам у відкритій, повній, своєчасній і зрозумілій формі, для прийняття ними раціональних рішень.

3 огляду на те, що транспарентність $€$ багатокритеріальною категорією, важливим є визначення їі складових елементів. Так, досліджуючи зміст транспарентності, Р. Хубієв відзначає, що це якісна характеристика підприємства, яка включає фінансову, технологічну, управлінську, правову, інформаційну та соціальну відкритість (прозорість) [12]. Погоджуючись в цілому з позицією автора, відзначимо сумнів щодо доцільності виділення такого елемента як «інформаційна прозорість». Підтримуючи думку [10], вважаємо, що саме інформація забезпечує певний рівень відкритості підприємства за окремими елементами. Обсяг і склад інформації становить основу всіх видів прозорості, що в сукупності і дозволяють говорити про певний рівень транспарентності. Враховуючи зазначене та спираючись на дослідження [11-12], виділимо такі основні елементи транспарентності як:

- фінансова транспарентність (передбачає повноту, ясність, достовірність, актуальність та доступність фінансової звітності підприємства);

- правова транспарентність (відкритість інформації щодо заснування підприємства, його власників, стану корпоративного управління, взаємовідносин 3 клієнтами, співробітниками, державними органами, даних щодо судових рішень);

- технологічна транспарентність (відкритість інформації щодо використання певних технологій під час виробництва товару (надання послуг), щодо джерел надходження сировини, основних партнерів);

- екологічна транспарентність (інформування суспільства щодо дотримання екологічних норм і стандартів, а також впровадження екологічно безпечних зразків товару);

- соціальна транспарентність (інформування щодо програм розвитку для працівників підприємства, реалізації соціальних проєктів, принципів діяльності на засадах соціальної відповідальності);

- адміністративна транспарентність (відкритість інформації щодо органів управління на підприємстві, відкритість процесу прийняття рішень).

Слід зазначити, що транспарентність як характеристика прозорості інформації повинна мати межу, яка б відділяла відкриту інформацію, необхідну для формування позитивного іміджу підприємства та задоволення інтересів стейкхолдерів від закритої, 
яка може нести загрозу економічній безпеці підприємства через їі розповсюдження. Крім того, між цими двома площинами є так звана «сіра зона», у якій існує реальна небезпека розкриття інформації, яка не призначена для цього, наприклад, шляхом комерційного шпіонажу або недоліків системи економічної безпеки (рисунок).

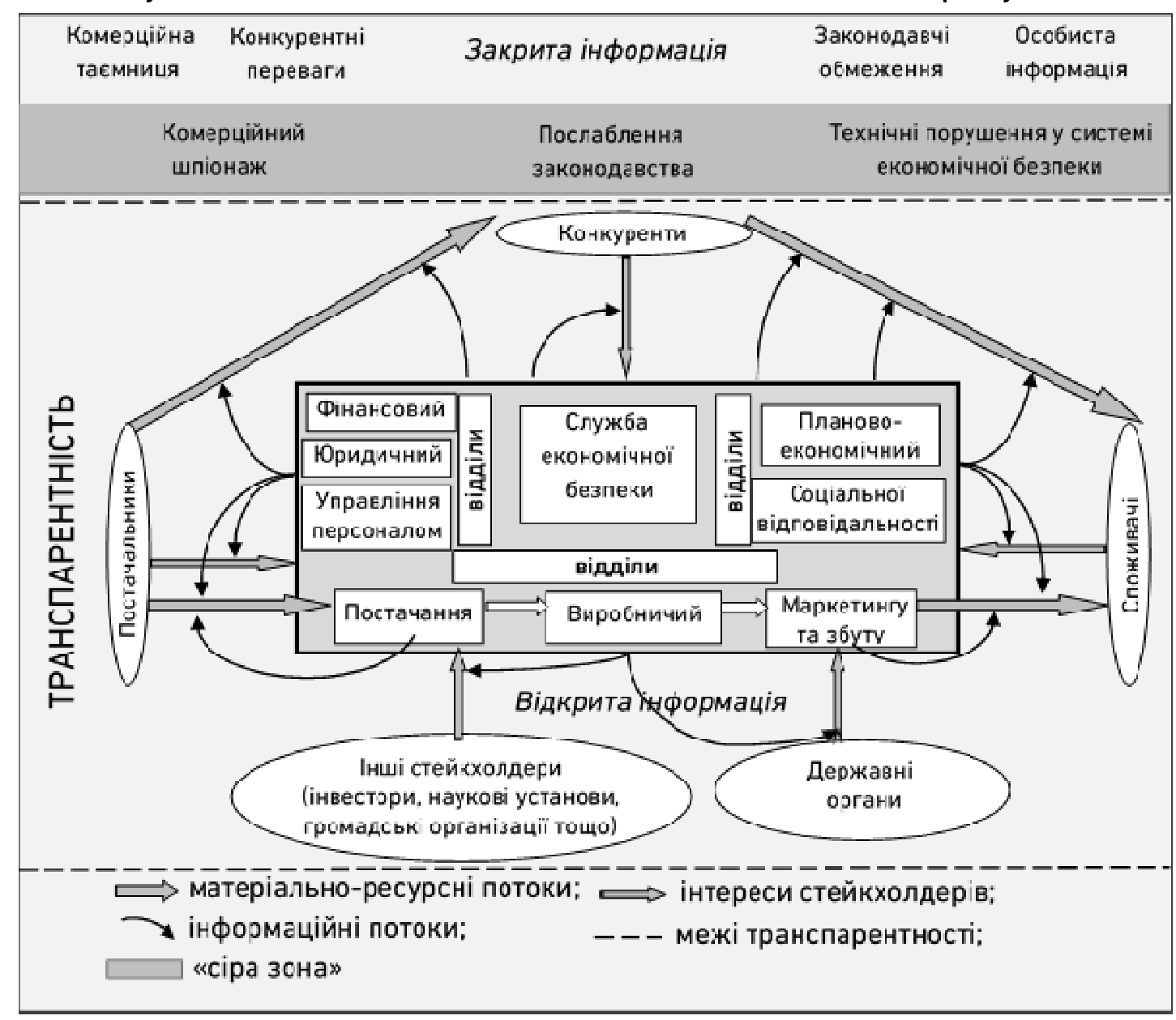

Рисунок. Концепт транспарентності діяльності підприємства Джерело: сформовано автором.

Різниця у розмірах зон відкритості та закритості інформації, а також площі «сірої зони» визначається 3 урахуванням галузевих особливостей транспарентності. Наприклад, зовсім різними будуть конфігурації транспарентного середовища для підприємства 3 виробництва паперових виробів та підприємства оборонної промисловості.

Основним показником, що характеризує забезпечення транспарентності вітчизняних підприємств, 3 урахуванням цифровізації їх діяльності, є індекс прозорості підприємств України. За результатами оцінювання сайтів підприємств (а також сторінок підприємств та їх керівників у соціальних мережах) за індексом прозорості, що ґрунтується на міжнародній методиці, яка розроблена 
Beyond Business (Ізраїль) та Центром «Розвиток корпоративної соціальної відповідальності» встановлено, що розкриття інформації із суттєвих питань корпоративної соціальної відповідальності для українських підприємств $€$ низьким, адже загальний рівень прозорості 100 найбільших підприємств - платників податків в Україні становить 25,5\%, тобто на своїх сайтах підприємства розкривають лише чверть інформації [15].

Здебільшого на корпоративних сайтах підприємств розміщено інформацію, що стосується охорони довкілля, трудових відносин, роботи 3 громадами, корпоративного управління, керівництва підприємств, складу наглядової ради, інформацію для інвесторів, щодо антикорупційних програм. На сайтах практично відсутня інформація про програми захисту прав людини, роботу 3 постачальниками та лідерства керівництва, в тому числі у соціальних питаннях. Не є розповсюдженою і практика розкриття інформації про структуру власності, створення структур управління корпоративною соціальною відповідальністю та залучення стейкхолдерів. Тільки 31 підприємство з числа найбільших платників податків України оприлюднило звіти про управління за 2019 рік. Нефінансові звіти оприлюднили на своїх сторінках тільки 6 підприємств (серед яких АТ «ПУМБ», ТОВ «Нова пошта», ПрАТ «Карлсберг Україна» та АТ «Фармак», АБ «Укргазбанк», НАК «Нафтогаз України»). 7 підприємств відзначили цілі сталого розвитку на сторінках корпоративних сайтів [15].

Підприємствами 3 найвищим рівнем розкриття інформації $є$ ДП «НАЕК «Енергоатом», АТ НАК «Нафтогаз України», ДП «НАЕК «Укренерго», ПАТ «АрселорМіттал Кривий Ріг», ПрАТ «Укргідроенерго», АТ «Фармак», АТ «Укрзалізниця». Тобто за секторальним аналізом найвищий рівень розкриття інформації у підприємств фінансової сфери, транспорту та постачання електроенергії. Найнижчий рівень прозорості у підприємств сфери будівництва та у секторі тимчасового розміщення й організації харчування. Державні підприємства мають практично по всіх критеріях і компонентах індексу прозорості вищі показники ніж компанії приватної форми власності.

3 урахуванням підвищення вимог урядів країн та інвесторів до звітування за соціальними і екологічними показниками діяльності, вітчизняним підприємствам доцільно активізувати свої зусилля щодо підготовки і оприлюднення нефінансових звітів та звітів про управління.

Висновки. На нашу думку, співпраця влади, бізнесу, науки та 
громадських організацій у питаннях формування інституціонального середовища цифрової безпеки та транспарентності підприємств грає ключову роль у підтримці умов для забезпечення економічної безпеки на різних рівнях. Враховуючи необхідність підвищення рівня транспарентності діяльності, вітчизняним підприємствам потрібно розміщувати інформацію щодо організації бізнесу, впровадження інновацій та корпоративної соціальної відповідальності на відповідних сторінках корпоративних сайтів, а не лише у звітах, враховуючи щораз більший інтерес з боку інвесторів, органів влади, експертного середовища та інших стейкхолдерів. При цьому потрібно враховувати межі транспарентності, 3 метою мінімізації загроз економічній безпеці підприємств.

1. Zingales L. Towards a Political Theory of the Firm. Journal of Economic Perspectives. 2017. Vol. 31. No. 3. P. 113-130. 2. Demchenko I., latsukh 0. The Problem of Unprofitable Activity of Enterprises in Ukraine. Baltic Journal of Economic Studies. 2018. Vol. 4. No. 2. P. 64-69. 3. Improvement of Public Financial Control in the Context of Ensuring Financial Security of the State / Meiss K.-M., Naumik-Gladka K., Krivtsiva T., Liadova Y. Economic Annals - XXI. 2017. Vol. 168. No. 11-12. P. 63-68. 4. Kubaichenko A. Classification of Forms of Shadow Economic Activity from the Viewpoint of Ensuring Economic Security. Baltic Journal of Economic Studies. 2018. Vol. 4. No. 1. P. 242-247. 5. Соломіна Г. В. Забезпечення фінансово-економічної безпеки підприємництва: навч. посіб. Дніпро: Дніпропетровський державний університет внутрішніх справ. 2018. 234 c. 6. Scott J. Measuring dimensions of perceived e-business risks. Information Systems and e-Business Management. 2004. Vol. 2. Iss. 1. P. 31-55. 7. Сталінська О. В. Система економічної безпеки підприємства в умовах розвитку цифрової економіки. Науковий вісник Міжнародного гуманітарного університету. Сер. Економіка і менеджмент. 2019. Вип. 38. С. 80-86. 8. Офіційний сайт РwC Україна. URL: https://www.pwc.com/ua/uk.html (дата звернення: 01.06.2021). 9. Нехай В. А. Інформаційна безпека як складова економічної безпеки підприємств. Науковий вісник Міжнародного гуманітарного університету. Сер. Економіка $i$ менеджмент. 2017. Вип. 24(2). С. 137-140. 10. Халіна В. Ю., Сироватський О. А. Транспарентність діяльності будівельного підприємства як детермінант довіри стейкхолдерів. Економічний простір. 2020. № 156. С. 166-170. 11. Krasnokutska N., Kruhlova 0., Kozub V., Martiskova P. Transparency of the enterprise: from theory to practice of evaluation (on the example of retail networks). Economic Annals-XXI. 2019. Vol. 175(1-2). P. 58-62. URL: http://soskin.info/userfiles/file/Economic-Annalspdf/DOI/ea-V175-10.pdf (дата звернення: 20.05.2021). 12. Хубієв Р. К. Транспаретність як фактор конкурентоспроможності. URL: https://www.econ.msu.ru/cmt2/lib/a/

1530/file/Hubiev.pdf (дата звернення: 17.05.2021). 13. Boone A. L., White J. T. The effect of institutional ownership on firm transparency and information production. Journal of Financial Economics. 2015. № 117(3). Р. 508-533. 14. Білоцька І. А. Транспарентність корпоративного сектору як передумова результативності бізнесу в Україні. Інвестиціі: практика та досвід. 2020. № 5-6. С. 56-58. URL: http://www.investplan.com.ua/pdf/5-6_2020/10.pdf. (дата звернення: 07.05.2021). 15. Індекс прозорості компаній України 2019. URL: https://cgpa.com.ua/wpcontent/uploads/2020/10/Transp_index_2019_ua_full_web.pdf (дата звернення: 30.05.2021). 


\section{REFERENCES:}

1. Zingales L. Towards a Political Theory of the Firm. Journal of Economic Perspectives. 2017. Vol. 31. No. 3. P. 113-130. 2. Demchenko I., latsukh 0. The Problem of Unprofitable Activity of Enterprises in Ukraine. Baltic Journal of Economic Studies. 2018. Vol. 4. No. 2. P. 64-69. 3. Improvement of Public Financial Control in the Context of Ensuring Financial Security of the State / Meiss K.-M., Naumik-Gladka K., Krivtsiva T., Liadova Y. Economic Annals - XXI. 2017. Vol. 168. No. 11-12. P. 63-68. 4. Kubaichenko A. Classification of Forms of Shadow Economic Activity from the Viewpoint of Ensuring Economic Security. Baltic Journal of Economic Studies. 2018. Vol. 4. No. 1. P. 242-247. 5. Solomina H. V. Zabezpechennia finansovo-ekonomichnoi bezpeky pidpryiemnytstva : navch. posib. Dnipro: Dnipropetrovskyi derzhavnyi universytet vnutrishnikh sprav. 2018. 234 s. 6. Scott J. Measuring dimensions of perceived e-business risks. Information Systems and e-Business Management. 2004. Vol. 2. Iss. 1. P. 31-55. 7. Stalinska 0. V. Systema ekonomichnoi bezpeky pidpryiemstva $\mathrm{v}$ umovakh rozvytku tsyfrovoi ekonomiky. Naukovyi visnyk Mizhnarodnoho humanitarnoho universytetu. Ser. Ekonomika i menedzhment. 2019. Vyp. 38. S. 80-86. 8. Ofitsiinyi sait PwC Ukraina. URL: https://www.pwc.com/ua/uk.html (data zvernennia: 01.06.2021). 9. Nekhai V. A. Informatsiina bezpeka yak skladova ekonomichnoi bezpeky pidpryiemstv. Naukovyi visnyk Mizhnarodnoho humanitarnoho universytetu. Ser. Ekonomika i menedzhment. 2017. Vyp. 24(2). S. 137-140. 10. Khalina V. Yu., Syrovatskyi 0. A. Transparentnist diialnosti budivelnoho pidpryiemstva yak determinant doviry steikkholderiv. Ekonomichnyi prostir. 2020. № 156. S. 166-170. 11. Krasnokutska N., Kruhlova 0., Kozub V., Martiskova P. Transparency of the enterprise: from theory to practice of evaluation (on the example of retail networks). Economic Annals-XXI. 2019. Vol. 175(12). P. 58-62. URL: http://soskin.info/userfiles/file/Economic-Annals-pdf/DOl/ea-V17510.pdf (data zvernennia: 20.05.2021). 12. Khubiiev R. K. Transparetnist yak faktor konkurentospromozhnosti. URL: https://www.econ.msu.ru/cmt2/lib/a/

1530/file/Hubiev.pdf (data zvernennia: 17.05.2021). 13. Boone A. L., White J. T. The effect of institutional ownership on firm transparency and information production. Journal of Financial Economics. 2015. № 117(3). R. 508-533. 14. Bilotska I. A. Transparentnist korporatyvnoho sektoru yak peredumova rezultatyvnosti biznesu $\mathrm{v}$ Ukraini. Investytsii: praktyka ta dosvid. 2020. № 5-6. S. 56-58. URL: http://www.investplan.com.ua/pdf/5-6_2020/10.pdf. (data zvernennia: 07.05.2021). 15. Indeks prozorosti kompanii Ukrainy 2019. URL: https://cgpa.com.ua/wpcontent/uploads/2020/10/Transp_index_2019_ua_full_web.pdf (data zvernennia: 30.05.2021). 


\author{
Liakhovych 0. 0. [1; ORCID ID: 0000-0002-6770-7970], \\ Candidate of Economics (Ph.D.), Associate Professor, \\ Oplachko I. O. [1; ORCID ID: 0000-0003-0591-121X], \\ Candidate of Economics (Ph.D.)
}

${ }^{1}$ National University of Water and Environmental Engineering, Rivne

\title{
ECONOMIC SECURITY AND TRANSPARENCY OF ENTERPRISES IN THE CONDITIONS OF DIGITALIZATION
}

The article is devoted to the economic security in the context of digitalization. Peculiarities of ensuring economic security including taking into account the transparency of enterprises in modern conditions of digital technologies development are described in this article. Digitalization as a factor of positive changes in the reputation of organizations, their financial component, increasing the level of competitiveness and innovation of business, and accordingly strengthening the market position are determined. In addition, it is stated that threats to the digital sector may disrupt the availability, integrity or confidentiality of the information systems on which economic activities are based. Accordingly, in this study, technology is determined, on the one hand, as a factor of development and a means of protection, and on the other as a source of threats.

Digital threats to economic security are systematized and basic ones for the business sector are identified. It is proposed to group digital threats to economic security into five basic blocks: systemic, structural, sectoral, business and personal. Along with this, a taxonomy of enterprise transparency and a concept of enterprise activity are determined, which takes into account the limits of transparency, which would neutralize threats to their economic security.

Recommendations to increase the level of transparency of domestic enterprises on the basis of digitalization and taking into account threats to economic security are given based on the results of the analysis of the enterprise transparency index. It is noted that the cooperation of government, business, science and NGOs in shaping the institutional environment of digital security and transparency of enterprises plays a key role in maintaining the conditions for economic security at various levels.

Given the need to increase transparency, domestic companies need to place information on business organization, innovation and corporate social responsibility on the relevant pages of corporate sites, and not just in reports, given the growing interest from investors, governments, experts and other stakeholders. It is necessary to take into account the limits of transparency, in order to minimize threats to the economic security of enterprises.

Keywords: economic security; digitization; threats; enterprise; transparency. 
Ляхович О. А. ${ }^{[1 ; O R C I D I D: 0000-0002-6770-7970], ~}$ К.э.Н., доцент,

Оплачко И. А. [1; ORCID ID: 0000-0003-0591-121X], К.Э.H.

${ }^{1}$ Национальный университет водного хозяйства и природопользования, г. Ровно

\section{ЭКОНОМИЧЕСКАЯ БЕЗОПАСНОСТЬ И ТРАНСПАРЕНТНОСТЬ ПРЕДПРИЯТИЙ В УСЛОВИЯХ ЦИФРОВИЗАЦИИ}

В статье проведено исследование сущности экономической безопасности в условиях цифровизации. Определены особенности обеспечения экономической безопасности, в том числе с учетом транспарентности предприятий в современных условиях развития цифровых технологий. Систематизированы цифровые угрозы экономической безопасности и определены базовые из них для предпринимательского сектора. Сформированы таксономия транспарентности предприятий и концепт деятельности предприятий, учитывающий пределы транспарентности, которые бы нейтрализовали угрозы их экономической безопасности. По результатам анализа индекса прозрачности предприятий даны рекомендации по повышению уровня транспарентности отечественных предприятий на основе цифровизации и с учетом угроз экономической безопасности.

Ключевые слова: экономическая безопасность; цифровизация; угрозы; предприятие; транспарентность. 